\title{
Minnesota peat viromes reveal insights into global viral ecology
}

Anneliek Maria ter Horst

Christian Santos-Medellín

Jackson W. Sorensen

Laura A. Zinke

Rachel M. Wilson

Eric R. Johnston

Gareth Trubl

Jennifer Pett-Ridge

Steven J. Blazewicz

Paul J. Hanson

Jeffrey P. Chanton

Christopher W. Schadt

Joel E. Kostka

Joanne B. Emerson

\section{Video Byte}

Keywords: Microbiome, viral ecology, viromics, soil viruses, soil microbial ecology, peat, metagenomics, biogeography, virome, niche partitioning, genomics, aquatic, terrestrial, peatland, Minnesota

Posted Date: March 1st, 2022

DOI: https://doi.org/10.21203/rs.3.rs-1405855/v1

License: (a) This work is licensed under a Creative Commons Attribution 4.0 International License. Read Full License 


\section{Abstract}

Viruses might be small, but they drive ecological change across the planet. That includes helping lock otherwise harmful carbon away in soil. Unfortunately, little is known about soil viruses worldwide. A recent study extensively examined the viral microbiome of a Minnesotan peatland from the experimental site SPRUCE. Peatlands are the largest natural terrestrial reservoirs of carbon on earth and, as such, are a critical component of the carbon cycle. The makeup of viral communities in the SPRUCE peat varied with sample depth, water content, and carbon chemistry factors. Of the 4,326 distinct virus types identified from SPRUCE, only 164 had been previously detected in other soils and those matches were almost exclusively from other peatlands. Peatlands are a very wet, but otherwise terrestrial, ecosystem. However, none of the previously detected aquatic viruses matched SPRUCE viruses, which suggests a terrestrial and aquatic 'species' divide. Instead, there was some evidence that the viruses in SPRUCE peat were adapting to the wet environment. More of the viruses that shared potential proteins with aquatic viruses in the database were found at waterlogged depths. This study expands our current understanding of soil viral communities and hints at the vast array of soil viruses yet to be discovered. 